\title{
Aqueous anise extract alleviated the pancreatic changes in streptozotocin-induced diabetic rat model via modulation of hyperglycaemia, oxidative stress, apoptosis and autophagy: a biochemical, histological and immunohistochemical study
}

\author{
M.A. Faried, A.E.S. El-Mehi \\ Anatomy and Embryology Department, Faculty of Medicine, Menoufia University, Egypt \\ [Received: 30 September 2019; Accepted: 16 October 2019]
}

Background: The present study aimed to investigate, for the first time to the best of our knowledge, the effect of aqueous anise extract on the pancreatic damage in the streptozotocin (STZ)-induced diabetic rat model with referral to some of its underlying mechanisms.

Materials and methods: Forty adult male albino rats were divided equally into four groups; control, anise extract treated (500 mg/kg orally once daily), diabetic control group (STZ $50 \mathrm{mg} / \mathrm{kg}$ once intraperitoneally) and diabetic group treated with anise extract. At the end of experiment (7 weeks), body weight, blood glucose and serum amylase levels were assessed. Pancreatic tissues were subjected to biochemical, histological (light and electron microscopic), and immunohistochemical studies.

Results: The diabetic group exhibited significant decrease in body weight and increase in blood glucose and serum amylase levels. Marked degenerative changes affecting both $\beta$-cells and acinar cells of the pancreas in the form of a significant decrease in islet's perimeter, vacuolated cytoplasm, pyknotic nuclei, depletion of zymogen granules, dilated congested blood vessels and degenerated organelles were reported. Hyperglycaemia-induced oxidative stress with subsequent upregulation of caspase 3 and beclin 1 immunoreaction were suggested to be implicated in diabetes mellitus pathogenesis. Anise extract ameliorated the all examined parameters via its hypoglycaemic and antioxidant properties with subsequent downregulation of apoptosis and autophagy.

Conclusions: Anise extract can be a promising agent in the control of diabetes mellitus for further clinical trials. (Folia Morphol 2020; 79, 3: 489-502)

Key words: anise, diabetes, pancreas, autophagy, apoptosis, oxidative stress, histopathology 


\section{INTRODUCTION}

Diabetes mellitus (DM) is increasingly becoming a global health problem affecting even young adults. Its prevalence all around the world is expected to increase at an alarming rate annually [21, 72]. About 415 million adult people suffer from DM which is expected to rise to 642 million people in 2040; and every 6 seconds a person dies due to DM [48].

Diabetes mellitus is considered as a group of metabolic disorders characterised by hyperglycaemia with disturbances of carbohydrate, protein and fat metabolism resulting either from defective insulin secretion (type 1), insulin action (type 2) or both [23]. Interestingly, it is now identified that both major types of DM affect $\beta$-cell mass and insulin secretion [46]. Thus, one of the important goals in the treatment of DM is the preservation of functional pancreatic $\beta$-cell that is mandatory to sustain euglycaemia [19].

Moreover, symptoms of exocrine pancreatic insufficiency have been observed in diabetic patients [37]. It is unclear whether the exocrine alteration in DM is related to the same factors that affect the $\beta$-cells causing their destruction or it is secondary to the loss of $\beta$-cell function [12].

Based on several experimental and clinical studies, it is now well accepted that DM is associated with increased production of free radicals and impaired antioxidant defences [15]. Recently, autophagy is known to play a pivotal role in a variety of degenerative conditions including Alzheimer's disease, DM and ageing [32].

Autophagy is a complicated and highly regulated process that plays an important role in maintaining the intracellular homeostasis and surviving via degrading and recycling intracellular proteins and damaged organelles. So, it is known as a "clear out" process [54]. The autophagic pathway can be stimulated by various factors such as oxidative stress, hypoxia, infection and physical exercise [10].

A lot of antihyperglycaemic drugs are available in the market nowadays but unfortunately with significant side effects [56]. Accordingly, there's increasing demands for antioxidant herbal products with anti-diabetic activity, less side effects and relatively low costs.

Pimpinella anisum L. (anise) is an annual herb with white flowers and small green to yellowish-brown seeds. It grows in Turkey, Iran, India, Egypt and many other warm regions of the world [52]. The principal constituents of anise are volatile oil, coumarins, fatty acids, flavonoid glycosides e.g. quercetin-3-glucuronide and rutin, proteins and carbohydrates. Anise powder and aqueous extract are used as carminatives, antiseptics, diuretics, digestives and as a remedy for insomnia and constipation [40]. Anise has also been reported to have antihaemolytic, anti-inflammatory [24, 30], anti-cancer [34], as well as anti-ulcer [5] and anti-osteoporosis characteristics [28]. Moreover, supplementation of diabetic patients with anise was previously found to have antioxidant, antihyperglycaemic and hypolipidaemic effects but this was based only on biochemical studies [53, 64].

In this work, we aimed to evaluate, for the first time to the best of our knowledge, the effect of aqueous anise extract on the structure of pancreas in streptozotocin (STZ)-induced diabetic rats with referral to the possible underlying mechanisms through biochemical, histological and immunohistochemical studies. We hypothesized that the antioxidant and antihyperglycaemic of anise extract would be reflected as amelioration of the histopathological changes in pancreas.

\section{MATERIALS AND METHODS}

\section{Chemicals}

Streptozotocin powder was obtained from Sigma-Aldrich Chemical Co. (St. Louis, Missouri, USA). The powder was stored at $-20^{\circ} \mathrm{C}$. The amount needed was freshly dissolved in distilled water immediately before use [26].

\section{Aqueous anise extract}

The dry and ripe seeds of pimpinella anisum L. plant (anise) were purchased from a local market, Menoufia, Egypt. These seeds were identified, and the extract was prepared by an expert taxonomist, Faculty of Science, Menoufia University, Egypt. To obtain the aqueous extract, the seeds of P. anisum $L$. were ground; $100 \mathrm{~g}$ of the powder were immersed in $1 \mathrm{~L}$ of distilled water, boiled for $15 \mathrm{~min}$ and filtered through Whatman paper No. 1 [9]. The filtrate was then evaporated to dryness under reduced pressure in a rotary evaporator [57].

\section{Animals}

This study was carried out on 40 adult male albino rats with an average weight of 180-200 g. The animals were housed at Theodor Bilharz Research Institute Animal House, Cairo, Egypt, at room temperature $25 \pm 2^{\circ} \mathrm{C}$ with a natural lighting cycle $(12 \mathrm{~h}$ 
dark/light cycle). They had free access to diet and tap water. Strict care and hygiene were provided to keep them in normal and healthy conditions. All experimental procedures were conducted with the approval of the Research Ethics Committee, Faculty of Medicine, Menoufia University, Egypt. This was in strict accordance with the requirement of National Research Council 2011 Guide for the Care and Use of Laboratory Animals: Eighth Edition. Washington, DC: The National Academies Press.

\section{Experimental design}

After an adaptation period of 1 week, the rats were randomly divided into four equal groups (10 rats each):

- group I (control group) - received no special treatment;

- group II (anise extract-treated group) - received anise extract, dissolved in $2 \mathrm{~mL}$ distilled water, once daily, orally by a gastric tube, at a dose of $500 \mathrm{mg} / \mathrm{kg}$ [9] for 7 weeks;

- group III (diabetic control group) - included STZ-induced diabetic rats;

- group IV (diabetes + anise extract group) - included STZ-induced diabetic rats which received anise extract at the same dose, route of administration and duration as group II.

\section{Induction of diabetes}

In groups III and IV, diabetes was induced by administration of a single intraperitoneal injection of STZ (50 mg/kg) to overnight fasted animals [60]. After $72 \mathrm{~h}$ of STZ injection, blood sample was withdrawn by retro-orbital puncture under light ether anaesthesia and the blood glucose level was measured. Rats with blood glucose level more than $250 \mathrm{mg} / \mathrm{dL}$ were considered diabetic [55] and chosen for this study.

At the end of the experimental period (7 weeks), the rats were weighed then anesthetised by inhalation of pentobarbital overdose $(200 \mathrm{mg} / \mathrm{kg})$. Blood samples were obtained from the retro-orbital venous plexus from all groups for biochemical study. A longitudinal incision of the anterior abdominal wall was made, and the pancreas was dissected out.

\section{Evaluation methods}

Biochemical study. The collected blood was divided into two portions. One portion was used to estimate fasting blood glucose level using blood glucose test strips (Accu-Chek; Diagnostic Solutions
Inc., Irvine, California, USA) and One Touch Basic Blood Glucose Meter (LifeScan Inc., Milpitas, California, USA). The other portion was left to clot then centrifuged at $3000 \mathrm{rpm}$ for $15 \mathrm{~min}$. The serum was separated and used for estimation of $\alpha$-amylase activity by commercially available kits.

Pancreatic specimens were homogenised. Homogenates were centrifuged at $10000 \times \mathrm{g}$ for $15 \mathrm{~min}$ at $4^{\circ} \mathrm{C}$. The supernatant was used for the measurement of tissue superoxide dismutase (SOD) and catalase according to the methods of Kono [38] and Aebi [2], respectively. Meanwhile, the concentration of malondialdehyde (MDA) was measured as an index of lipid peroxidation [49].

\section{Histological studies}

Light microscopic examination. The pancreas was removed immediately from each animal and then washed with physiological saline $(0.9 \% \mathrm{NaCl})$ for removal of the blood that might hinder the fixation process. Pancreatic specimens were fixed in 10\% neutral formalin for $24 \mathrm{~h}$, dehydrated in ascending grades of alcohol, cleared and embedded in paraffin. Sections of $5 \mu \mathrm{m}$ thick were cut by microtome and subjected to haematoxylin and eosin (H\&E) staining for routine histological examination.

Ultrastructural examination. Small pancreatic specimens, $1 \mathrm{~mm}$ each, taken from all experimental groups were prepared for transmission electron microscopic (TEM) study. The specimens were fixed in $3 \%$ glutaraldehyde in sodium phosphate buffer,

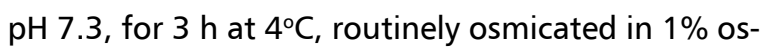
mium tetroxide and then processed. Semithin sections were stained with toluidine blue stain and were examined under light microscope as a preliminary step. Ultrathin sections were stained with lead citrate and uranyl acetate and were examined under transmission electron microscope.

\section{Immunohistochemical study}

Paraffin sections ( $5 \mu \mathrm{m}$ thick) on poly-L-lysin coated slides were deparaffinised in xylene for 1-2 min and rehydrated in descending grades of ethanol $(100 \%, 95 \%$, and $70 \%$ ethanol) two changes $5 \mathrm{~min}$ each, then brought to distilled water for another $5 \mathrm{~min}$. Endogenous peroxidase was blocked by inserting the sections in $3 \%$ hydrogen peroxide $\left(\mathrm{H}_{2} \mathrm{O}_{2}\right)$. The microwave antigen retrieval procedure was performed. The sections were incubated with primary anti-insulin antibody (guinea pig polyclonal, Abcam, 
dilution 1:100), anti-caspase 3 antibody (rabbit polyclonal, Lab Vision, USA, dilution 1:500) and anti-beclin 1 antibody (rabbit polyclonal, Abcam, dilution 1:200). After that, biotinylated goat-polyvalent secondary antibody was applied. The sections were then incubated in preformed streptavidin peroxidase and finally the prepared DAB substrate chromogen (3,3'-diaminobenzidine tetrahydrochloride) was applied and the slides were counterstained with haematoxylin to be examined under light microscope.

\section{Quantitative assessment}

Using Image J software, version $\mathrm{K} 1.45$, the following parameters were measured:

- the islet's perimeter $(\mu \mathrm{m})$;

- the area per cent of insulin, caspase 3 and beclin 1 immunoreaction.

For each parameter, 5 non-overlapping fields (40x) for every specimen (from 5 different rats/each group) were randomly taken using a Leica DML B2/11888111 microscope equipped with a Leica DFC450 camera.

\section{Statistical analysis}

The data were collected, tabulated and analysed by SPSS (statistical package for social science) version 23.0 on IBM compatible computer (SPSS Inc., Chicago, IL, USA). Results were expressed as mean \pm standard deviation. The significance differences between groups were evaluated using one way-ANOVA followed by post hoc Bonferroni test. A $p$ value of $<0.05$ was considered statistically significant.

\section{RESULTS}

There was no significant difference in the all examined parameters between the control and anise extract treated groups.

\section{Body weight results}

At the end of the experiment, there was a significant decrease $(p<0.001)$ in the body weight in the diabetic group (130.64 \pm 4.29 vs. $248.15 \pm 5.22)$ compared to the control group. On the other hand, the diabetic group treated with anise extract showed a significant increase $(p<0.001)$ in its weight $(205.06 \pm$ \pm 2.91 vs. $130.64 \pm 4.29$ ) compared to the diabetic control group (Fig. 1A).

\section{Biochemical results}

There was a significant increase $(p<0.001)$ in the blood glucose level in the diabetic group $(396.78 \pm$
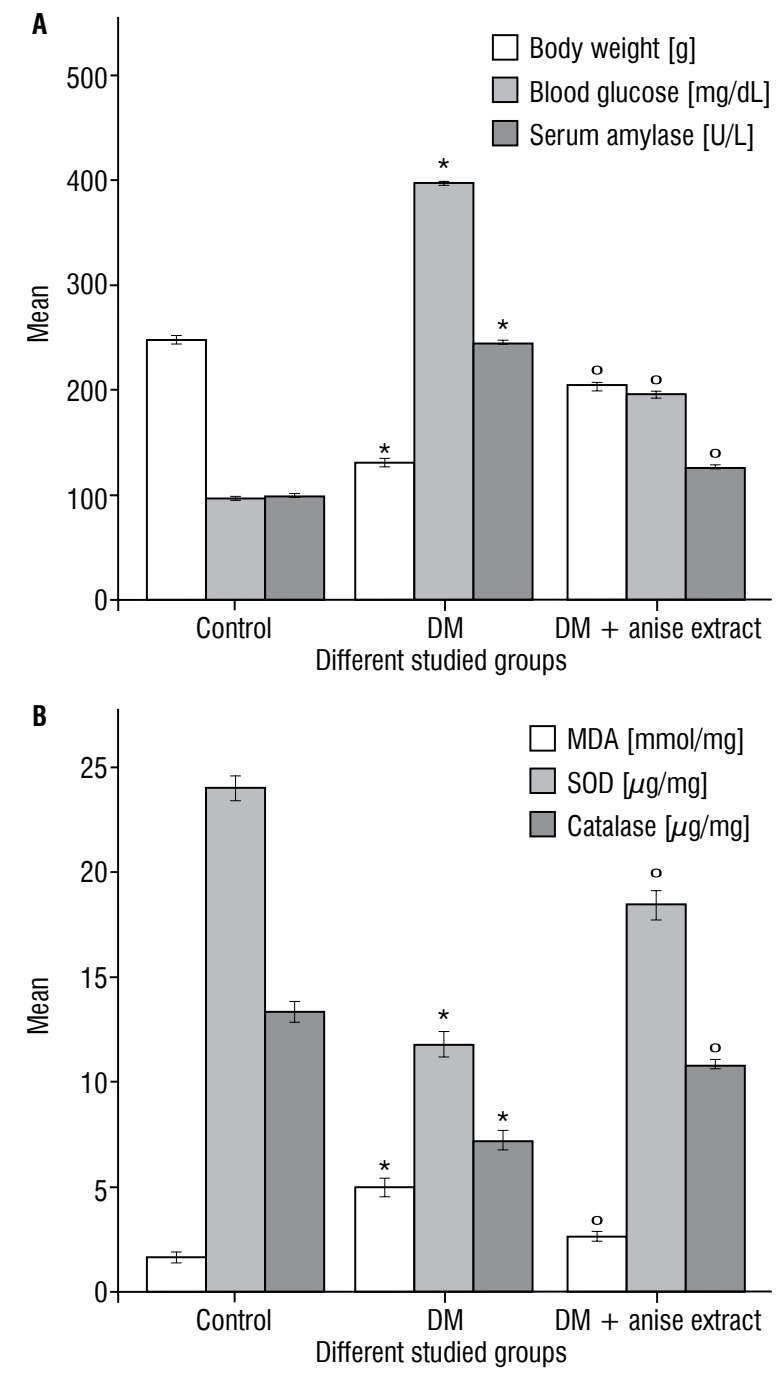

Figure 1. A. A histogram showing a significant decrease in the body weight and increase in the blood glucose level and serum amylase in the diabetic group compared to the control group $\left({ }^{*} p<0.001\right)$. These values are significantly improved in the diabetic group treated with anise extract compared to the diabetic control group $\left({ }^{\circ} \mathrm{p}<0.001\right)$; B. A histogram revealing a significant increase in the pancreatic malondialdehyde (MDA) level and decrease in superoxide dismutase (SOD) and catalase compared to the control group $\left({ }^{*} p<0.001\right)$ that was significantly alleviated in diabetic group treated with anise extract $\left({ }^{0} \mathrm{p}<0.001\right.$ compared to the diabetic control group); $\mathrm{DM}$ - diabetes mellitus.

\pm 6.15 vs. $96.77 \pm 1.34$ ) compared to the control group. This level was significantly decreased $(p<0.001)$ in the diabetic group treated with anise extract (195.46 \pm \pm 5.09 vs. $396.78 \pm 6.15)$ when compared to the diabetic control group (Fig. 1A).

Regarding the serum amylase level, a significant increase $(p<0.001)$ in its level was noted in the diabetic group $(244.36 \pm 4.69$ vs. $99.08 \pm 2.80)$ compared to the control group, while the diabetic group treated with anise extract exhibited a signifi- 

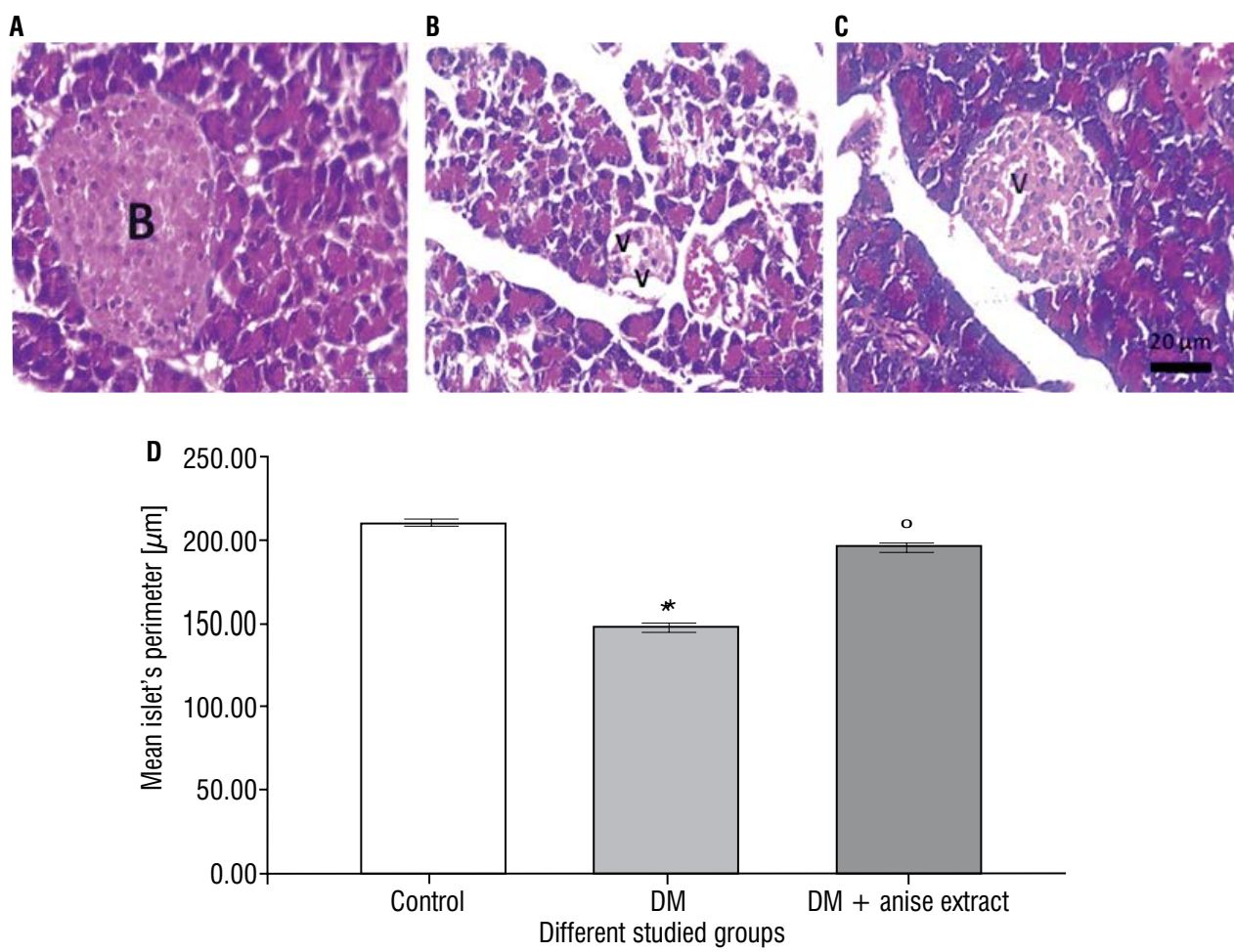

Figure 2. A-C. Representative photomicrographs of haematoxylin and eosin stained sections of rat pancreas in the different experimental groups; A. Islet's of Langerhans of the control group showing centrally placed normal $\beta$-cells (B); B. Streptozotocin-induced diabetic group showing apparent reduction in the islet size. Most of its $\beta$-cells are lost and marked vacuolations (V) are seen; C. Diabetic group treated with anise extract revealing regaining of nearly normal $\beta$-cells except for mild vacuolation (V); H\&E, scale bar $=20 \mu \mathrm{m}, 40 \times$ ); D. A histogram showing a significant decrease in the islet's perimeter in the diabetic group compared to the control group $\left({ }^{*} p<0.001\right)$ as well as a significant increase in its perimeter in the diabetic group treated with anise extract compared to the diabetic untreated group ( $\left.{ }^{\circ} p<0.001\right)$; $\mathrm{DM}$ — diabetes mellitus.

cant decrease $(p<0.001)$ in the serum amylase level (125.81 \pm 3.60 vs. $244.36 \pm 4.69)$ compared to the diabetic control group (Fig. 1A).

The assessment of MDA, SOD and catalase levels in the pancreatic homogenates revealed a significant increase $(p<0.001)$ in MDA level $(4.88 \pm 0.59$ vs. $1.57 \pm 0.35)$ and a significant decrease $(p<0.001)$ in SOD and catalase levels in the diabetic group (11.73 \pm \pm 0.90 vs. $23.89 \pm 0.87 ; 7.10 \pm 0.69$ vs. $13.20 \pm 0.83$, respectively) compared to the control group. Indeed, the diabetic group treated with anise extract displayed a significant decrease $(p<0.001)$ in the MDA level $(2.59 \pm 0.27$ vs. $4.88 \pm 0.59)$ and a significant increase $(p<0.001)$ in SOD and catalase levels ( $18.32 \pm 0.84$ vs. $11.73 \pm 0.90 ; 10.60 \pm 0.57$ vs. $7.10 \pm 0.69$, respectively) when compared to the diabetic control group (Fig. 1B).

\section{Histological results}

Light microscopic study. H\&E stained pancreatic sections from the control group showed normal histological architecture. The endocrine part showed pale stained islets of Langerhans scattered between the acini, most of its cells were centrally located $\beta$-cells with rounded nuclei (Fig. 2A). The diabetic group exhibited marked degenerative changes with apparent decrease in the islet's size. Loss of many cells of islets of Langerhans was a prominent feature. Marked cytoplasmic vacuolations were observed (Fig. 2B). In contrast, the diabetic group treated with anise extract showed apparent increase in islet's size with marvellous amelioration of most of degenerative changes except for presence of mildly vacuolated $\beta$-cells (Fig. 2C). Statistically, there was a significant decrease $(p<0.001)$ in the islet's perimeter in the diabetic group (148.24 \pm 2.80 vs. $210.51 \pm 2.37$ ) compared to the control group. The diabetic group treated with anise extract showed a significant increase $(p<0.001)$ in islet's perimeter $(196.42 \pm 2.85$ vs. $148.24 \pm 2.80)$ compared to the diabetic control group (Fig. 2D).

The exocrine portion of the control group displayed highly packed acini within the pancreatic lobules that were separated by narrow interlobular septa. 
A

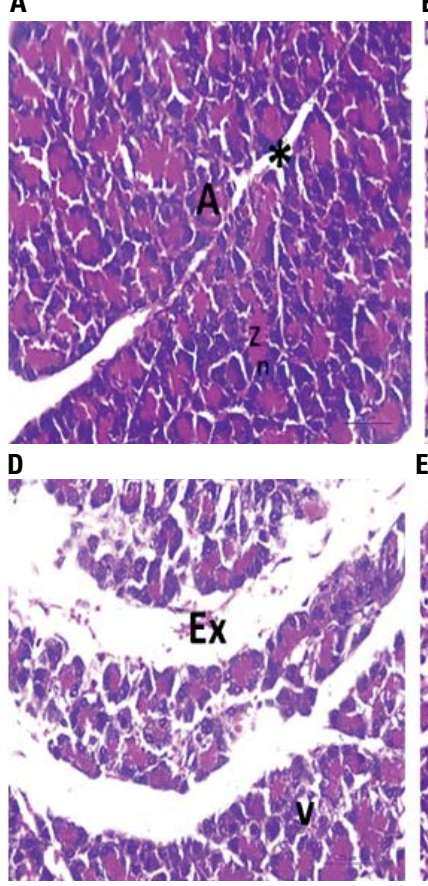

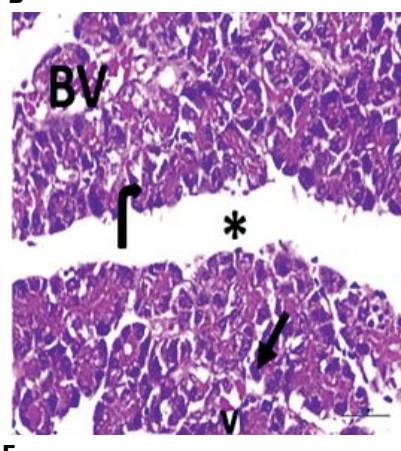

C

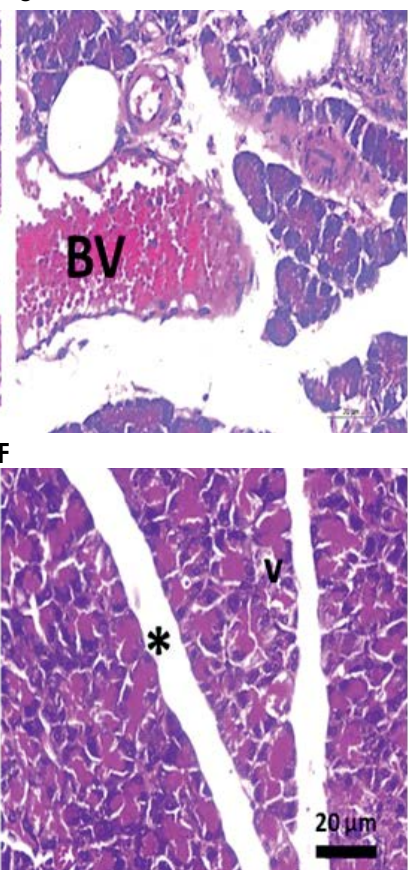

Figure 3. Representative micrographs of haematoxylin and eosin stained sections showing exocrine portion of the pancreas of the different experimental groups; A. Control group showing pancreatic lobules separated by interlobular septa (asterisk). Each lobule consists of acini (A) with rounded nuclei $(\mathrm{n})$ and supranuclear zone contains acidophilic zymogen granules (Z); B-E. Streptozotocin-induced diabetic group showing many degenerative changes in the form of marked separation between the pancreatic lobules (asterisk), darkly stained pyknotic acinar nucle (arrow), cytoplasmic vacuolations (V), decrease in zymogen granules (bent arrow), dilated congested blood vessel (BV), extravasation (Ex) and accumulation of inflammatory infiltrates (double arrows); $\boldsymbol{F}$. Diabetic group treated with anise extract showing restoration of the nearly normal lobular architecture except for mild separation between the pancreatic lobules (asterisk) and a few cytoplasmic vacuolation (V); $\mathrm{H} \& \mathrm{E}$, scale bar $=20 \mu \mathrm{m}, 40 \times$.

Each acinar cell had a rounded basal nucleus and apical acidophilic zymogen granules (Fig. 3A). However, the diabetic group revealed marked separation between the pancreatic lobules, congested dilated blood vessels, extravasation and intense inflammatory infiltration. Most of acinar cells showed pyknotic nuclei with cytoplasmic vacuolation and decreased zymogen granules. (Fig. 3B-E). In contrary, the diabetic group treated with anise extract showed restoration of the normal architecture except for the presence of mild separation of pancreatic acinar lobules and a few cells with cytoplasmic vacuolation (Fig. 3F).

Transmission electron microscopic study. TEM examination of the $\beta$-cells of rats' pancreas of the different studied groups was done. The control group revealed normal architecture of the islets of Langerhans formed mainly of $\beta$-cells; each with an euchromatic nucleus, well developed rough endoplasmic reticulum $(\mathrm{rER})$ and mitochondria in addition to many electron dense secretory granules surrounded by lucent halos (Fig. 4A). On the other hand, the diabetic group exhibited distortion of the architecture of $\beta$-cells. Some nuclei showed chromatolysis and others were pyknotic. Intense cytoplasmic rarefication and marked vacuolations as well as degenerated mitochondria, cystic dilatation of the rER and dilated Golgi were obviously noted (Fig. 4B, C). Diabetic group treated with anise extract displayed more or less normal architecture of the $\beta$-cells. However, slightly condensed chromatin, few vacuoles, dilated Golgi and few slightly degenerated mitochondria were encountered (Fig. 4D).

Transmission electron microscopic study of the acini of rats' pancreas was examined. The control group showed acinar cells each with euchromatic nucleus, well developed organelles as mitochondria and $r E R$. Numerous electron dense secretory granules (zymogen granules) at the apical part were noted (Fig. 5A). The diabetic group revealed marked acinar changes with widening of the intercellular spaces. Nuclear changes in the form of peripheral chromatin condensation, irregularity of the nuclear membrane with perinuclear space were observed. Some cells exhibited shrunken and pyknotic nuclei. In addition, swollen degenerated mitochondria with disintegrated 
A

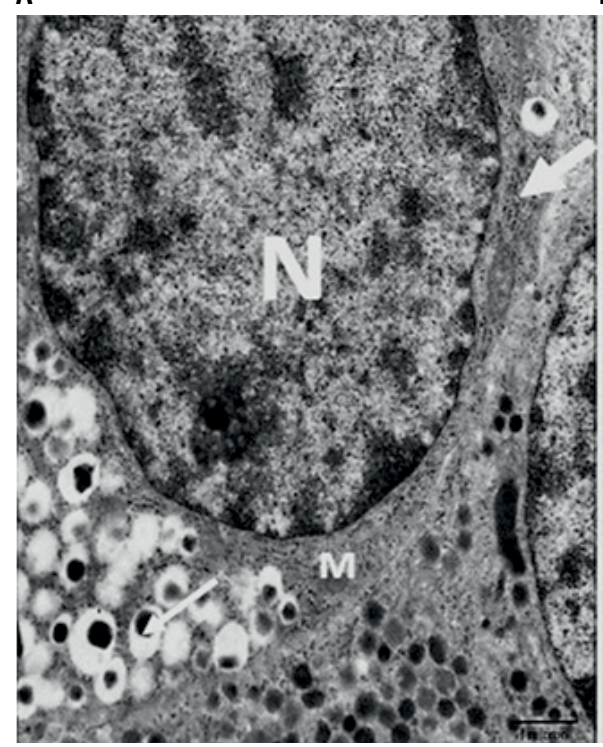

C

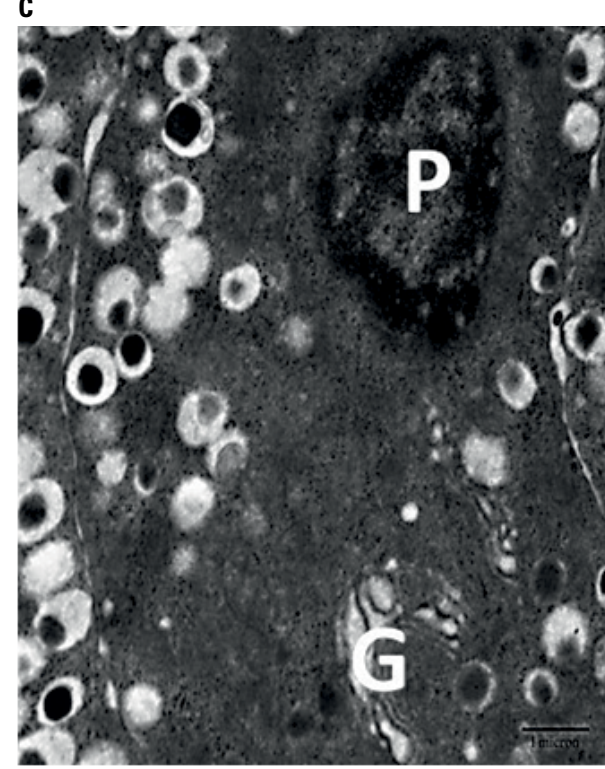

B

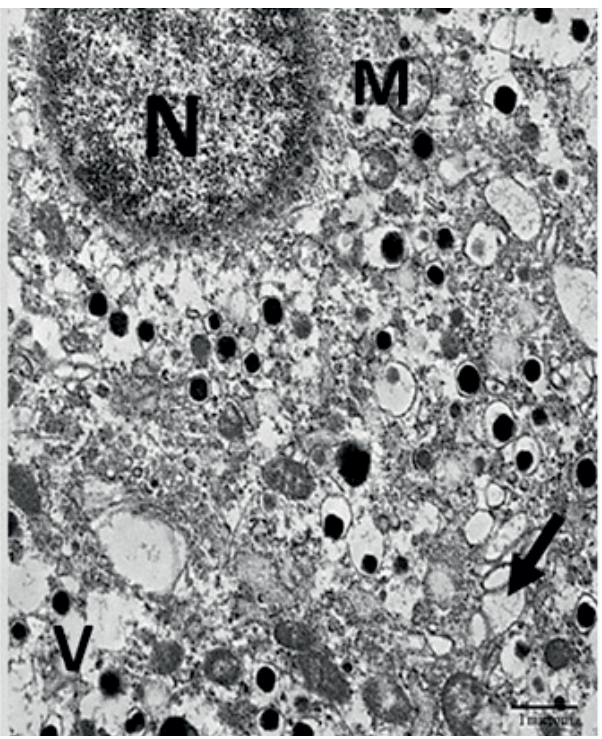

D

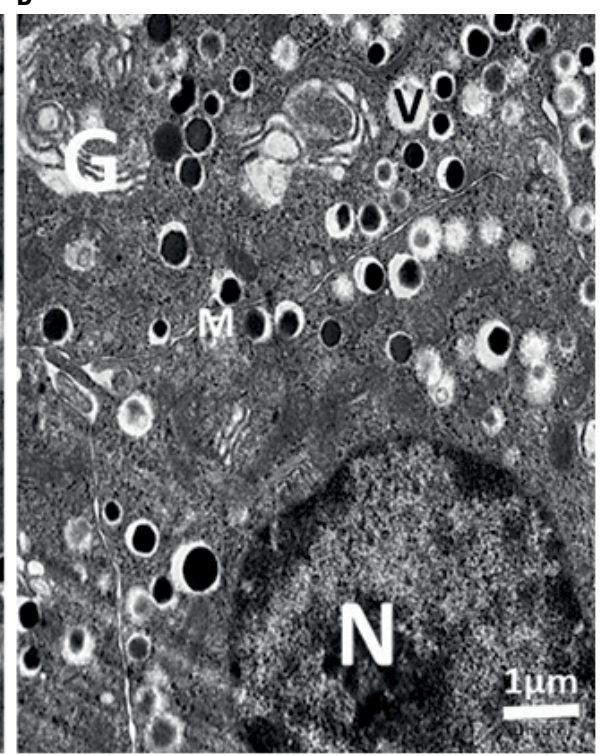

Figure 4. Electron photographs of part of rats' islets of Langerhans of the different experimental groups; A. Control group showing normal architecture of the $\beta$-cell with euchromatic nucleus (N), well developed mitochondria (M), rough endoplasmic reticulum (thick arrow) and electron dense secretory granules surrounded by lucent halos (thin arrow); B, C. Streptozotocin-induced diabetic group showing distortion of the architecture with marked degenerative changes of $\beta$-cells in the form of nuclear chromatolysis $(\mathrm{N})$, electron dense pyknotic nuclei $(\mathrm{P})$, cytoplasmic rarefaction and marked vacuolation (V), degenerated mitochondria (M), cystic dilatation of the rough endoplasmic reticulum (arrow) and dilated Golgi (G); D. Diabetic group treated with anise extract revealing a more or less normal $\beta$-cell except for slight chromatin condensation (N), few small vacuoles (V), dilated Golgi apparatus (G) and few slightly degenerated mitochondria (M); TEM $\times 17500$, scale bar $=1 \mu \mathrm{m}$.

cisternae, dilated rER, decreased electron density and depletion of zymogen granules and large cytoplasmic vacuolations were noted. Vacuoles contained cellular debris mostly autophagic vacuoles were also seen (Fig. 5B-E). On contrast, the diabetic group treated with anise extract exhibited restoration of the normal pancreatic architecture except for some scattered few small vacuolations and mildly degenerated mitochondria and slightly condensed chromatin (Fig. 5F).

\section{Immunohistochemical results}

Immunohistochemically, there was a significant decrease $(p<0.001)$ in insulin immunoreaction in the diabetic group $(5.10 \pm 0.57$ vs. $23.28 \pm 1.23)$ compared to the control one. Moreover, diabetic group treated with anise extract showed a significant increase $(p<0.001)$ in insulin immunoreaction (17.69 \pm 0.81 vs. $5.10 \pm 0.57)$ compared to the diabetic control group (Fig. 6A-C, J). 
A

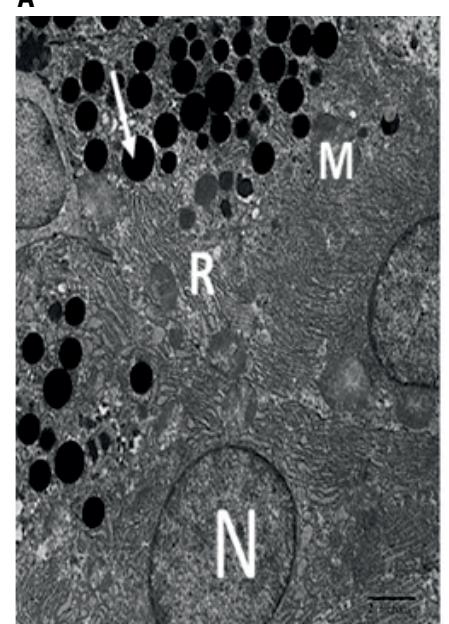

D

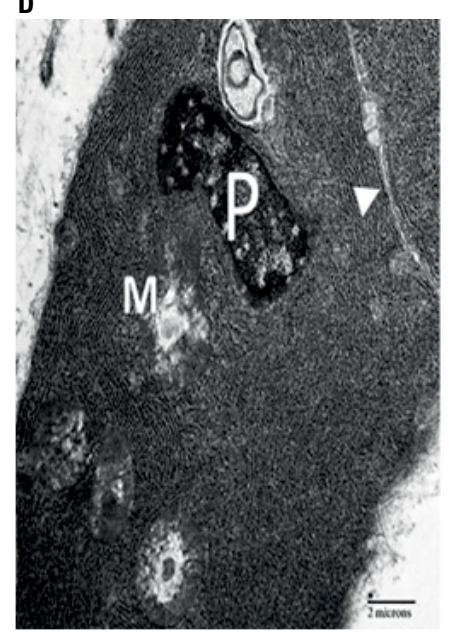

B
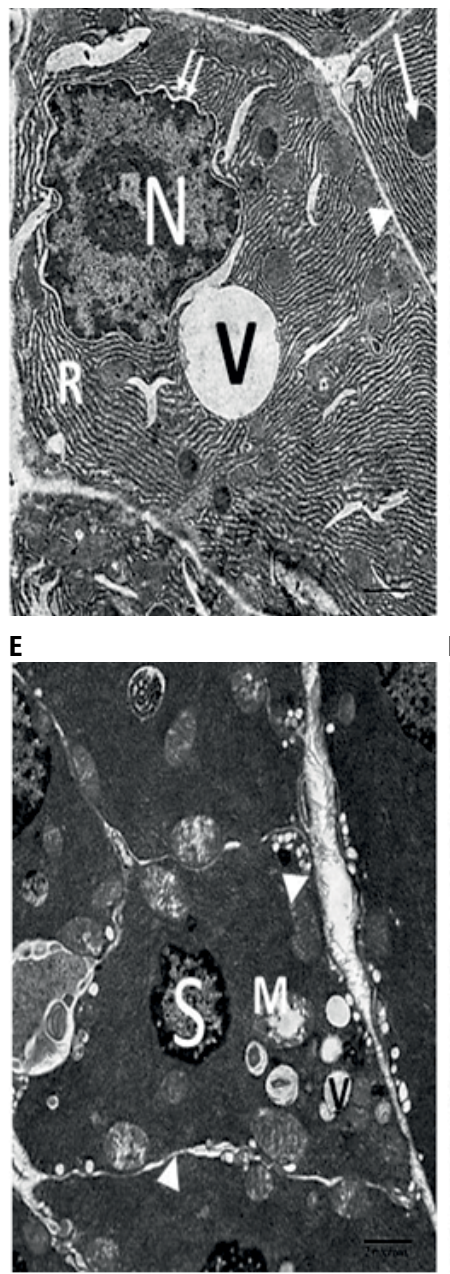

C

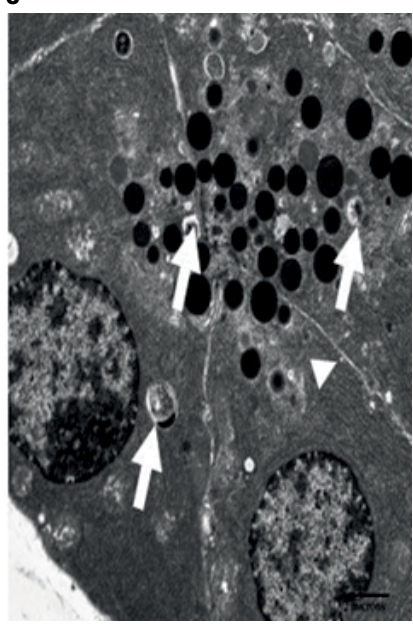

$\mathbf{F}$

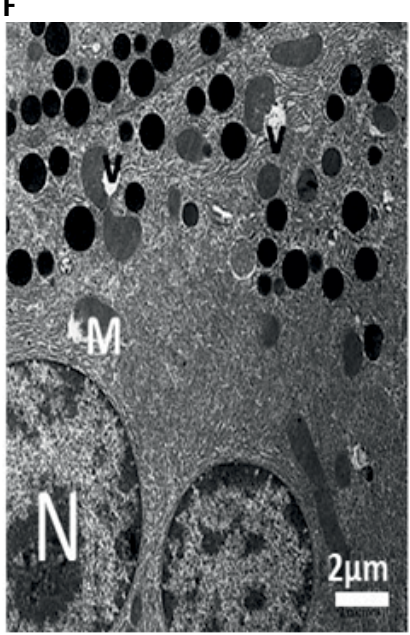

Figure 5. Electron micrographs of rat exocrine pancreas of the different experimental groups; A. Control group showing acinar cells with euchromatic nuclei $(N)$, well developed mitochondria $(M)$, rough endoplasmic reticulum $(R)$ and numerous electron dense secretory granules (arrow) at the apical part; B-E. Streptozotocin-induced diabetic group revealing marked acinar changes represented by marked widening of the intercellular spaces (arrow head), nuclear changes in the form of peripheral chromatin condensation (N) with irregularity of the nuclear membrane and perinuclear space (double arrows). Some nuclei are shrunken (S) and pyknotic (P). Swollen degenerated mitochondria (M), dilated rough endoplasmic reticulum $(R)$, decreased electron density and depletion of zymogen granules (thin arrow) and large cytoplasmic vacuolation (V) compressing the nuclear membrane are seen. Vacuoles with cellular debris mostly autophagic vacuoles (thick arrows) are also noted; $\mathbf{F}$. Diabetic group treated with anise extract showing restoration of the normal pancreatic architecture except for slight chromatin condensation (N), few small vacuoles (V) and mild mitochondrial lysis (M); TEM $\times 12000$, scale bar $=2 \mu \mathrm{m}$.

Regarding the caspase 3, a significant increase $(p<0.001)$ in its immunoreaction was noted in the diabetic group ( $52.96 \pm 2.32$ vs. $1.07 \pm 0.11)$ compared to the control group. On the other hand, there was a significant decrease $(p<0.001)$ in its immunoreaction in the diabetic group treated with anise extract $(22.34 \pm 1.27$ vs. $52.96 \pm 2.32)$ compared to the diabetic control group (Fig. 6D-F, J).

Moreover, therewas a significantincrease $(p<0.001)$ in beclin 1 immunoreaction in the diabetic group $(46.85 \pm 1.30$ vs. $30.31 \pm 0.86)$ compared to the control group. The diabetic group treated with anise extract exhibited a significant decrease $(p<0.001)$ in its immunoreaction $(31.55 \pm 1.05$ vs. $46.85 \pm 1.30)$ compared to the diabetic control group (Fig. 6G-I, J.

\section{DISCUSSION}

Currently, DM is one of the major health concerns globally [6]. Unfortunately, uncontrolled hyperglycaemic condition for a long period can cause end-organ damage with high rate of morbidity and even mortality [42].

Although several drugs, either insulin or oral hypoglycaemic drugs, are used in attempt to control DM, perfect control is rarely achieved. Moreover, these 

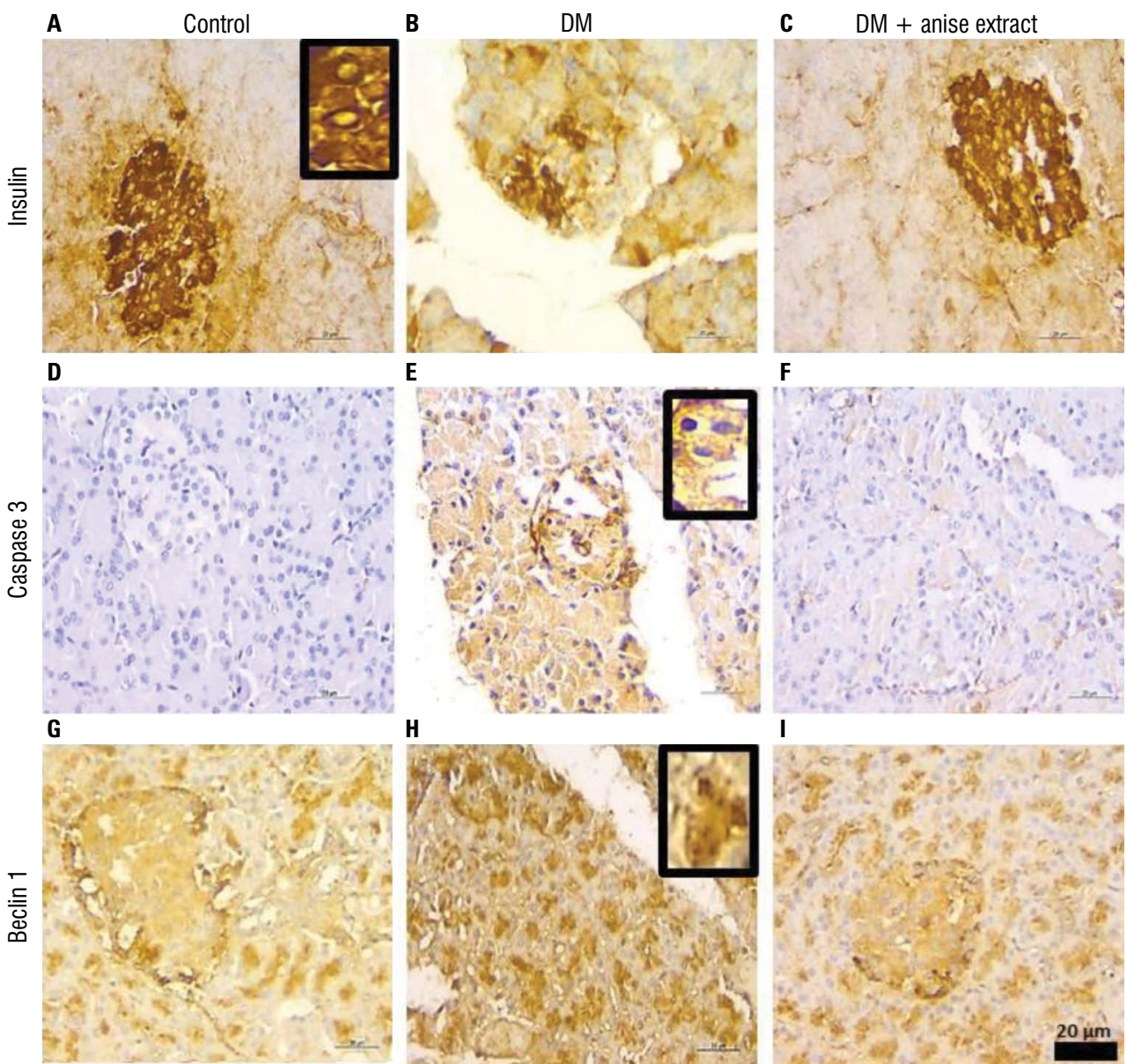

H
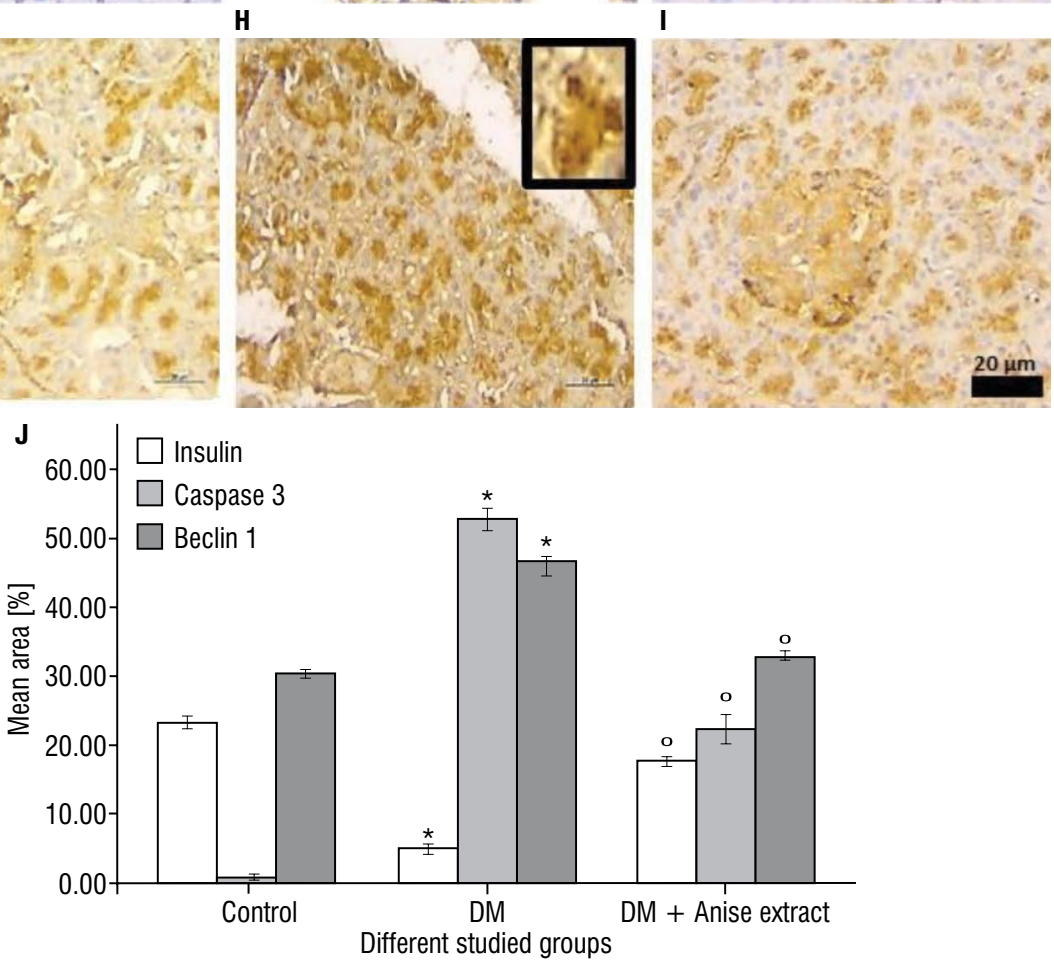

Figure 6. A-I. Representative micrographs of immuno-stained pancreatic sections from the different studied groups showing decrease in insulin and increase in caspase 3 and beclin 1 positive immunoreaction in the diabetic group compared to the control group. Diabetic group treated with anise extract reveals increase in insulin and decrease in caspase 3 and beclin 1 immunoreaction compared to the diabetic untreated group. Inserts indicates the positive immunoreaction (scale bar $=20 \mu \mathrm{m}, 40 \times$ ); J. A histogram showing a significant decrease in insulin and increase in caspase 3 and beclin 1 area per cent immunoreaction in the diabetic group compared to the control group ( $\left.{ }^{*} p<0.001\right)$. The diabetic group treated with anise extract shows a significant increase in insulin and decrease in caspase 3 and beclin 1 area per cent immunoreaction compared to the diabetic group ( $\left.{ }^{\circ} \mathrm{p}<0.001\right)$; $\mathrm{DM}$ - diabetes mellitus.

drugs have many side effects as hypoglycaemia at higher doses, hepatic affection, neurological disturbance and digestive disorders. So, searching for new medications with safe and effective properties for DM control is highly important. Recently, the use of medical plants as alternative remedies is encouraged for the treatment of several disorders including DM $[16,63]$.

Therefore, the present study aimed, for the first time to the best of our knowledge, to investigate 
the role of aqueous anise extract in ameliorating the biochemical and histological alterations in STZ diabetic rat model with referral to some of its underlying mechanisms.

Streptozotocin is a well-known diabetogenic agent with longer half-life and sustained hyperglycaemia for longer duration than other diabetogenic agents [69]. A single high dose STZ produced a rapid ablation of $\beta$-cells and hence used for induction of type 1 DM [67] as confirmed, in this study, by the significant increase in blood glucose level and significant downregulation of insulin immunoreaction as well as by the degenerative changes of $\beta$-cells observed in the diabetic control group. It specifically destroys $\beta$-cells via alkylation and thus fragmentation of deoxyribonucleic acid (DNA) [14]. This model presents a chronic pathological pattern like human as clarified by Tourreal et al. [70] and Srinivasan et al. [68]. So, the commonly used chemical-induced models in the field of diabetes researches for assessing the mechanism of DM, searching for potential therapies for this disease, and evaluating treatment options are the STZ-induced models $[33,75]$.

Increased glucose concentration leads to free radical production and depletion of antioxidant defences producing a state of oxidative stress that in turn produces more $\beta$-cells destruction [44]. The dose of aqueous aniseed extract used in the study, $500 \mathrm{mg} / \mathrm{kg}$, was proved previously to have antioxidant properties [9]. According to the toxicity classification, anise is particularly non-toxic at this dose because its $\mathrm{LD}_{50}$ value is more than $5 \mathrm{~g} / \mathrm{kg}$ [29]. Furthermore, aqueous anise extract is preferred than ethanolic one as it had much more antioxidant capacity as reported by Gulcin et al. [24].

In the present study, anise extract exerted a significant hypoglycaemic effect compared to the diabetic control group. This is mostly attributed to its ability to increase the insulin secretion as confirmed by the significant upregulation of insulin immunoreaction. previous researches postulated that some of phenolic compounds in anise extract interfere with the glucose absorption [51], facilitate peripheral tissue utilisation of glucose via an insulin dependent glucose transporter [17] and restore insulin sensitivity [31]. This agreed with Shobha and Andallu [64] who investigated the hypoglycaemic effect of anise extract in vitro. They attributed its hypoglycaemic effect to its antioxidant property, as established in our study by the significant decrease in MDA and increase in catalase and SOD by anise extract supplementation.

The diabetic group treated with anise extract in the current study showed a significant increase in body weight compared to the diabetic control group. This may be attributed to its hypoglycaemic properties preventing hyperglycaemia-induced protein loss. Moreover, Bekara et al. [9] referred the role of anise in body weight gain to its bioactive compounds that have stimulant effect on the digestive system such as anethole, eugenol, anisaldehyde, estragol and methylchavicol. Furthermore, anise is rich in nutritive compounds that have a positive effect on body weight gain like: proteins $18 \%$, fatty oil $8-23 \%$, essential oil $2-7 \%$, sugars $3-5 \%$ and crude fibre $12-15 \%[8,9]$.

In this research, $\beta$-cells and exocrine acini of pancreas were affected in the diabetic group. The islets of Langerhans in the diabetic group, in this study, showed a significant decrease in their perimeter in addition to marked distortion in the $\beta$-cell architecture in the form of presence of pyknotic nuclei, mostly apoptotic as proved by the significant upregulation of caspase 3 , chromatolysis, cytoplasmic rarefication and vacuolation in addition to degenerated mitochondria, dilated Golgi and cystic dilatation of the rER. Moreover, the exocrine portion demonstrated marked separation of the pancreatic lobules, dilated congested blood vessel, darkly stained pyknotic acinar nuclei and vacuolations. Wide intercellular spaces, swollen degenerated mitochondria, dilated $\mathrm{rER}$, decreased electron density and depletion of zymogen granules were also noted. These findings were in consistence with previous studies that examined the histological pancreatic changes in diabetic models $[1,4,22,47,66]$.

Although the antioxidant and hypoglycaemic properties of anise extract was studied previously at the biochemical level [64], the present study correlate the biochemical results with histological and ultrastructure changes in diabetic rat model and investigate the role of anise extract on DM-induced apoptosis and autophagy in the pancreatic tissue.

The diabetic group treated with anise extract presented with a significant improvement of the structure of $\beta$-cells, with a significant increase in insulin immunoreaction, and the pancreatic acini, with a significant decrease in amylase as compared to the diabetic control group.

This beneficial effect of anise extract could be explained by considering the pathophysiology of DM. 
Oxidative stress plays a crucial role in the pathogenesis of development and progression of DM [59]. This was confirmed in this research by the significant decrease in antioxidant enzymes (SOD and catalase) and increase in the level of MDA, a marker for lipid peroxidation, and this was in line with Sifuentes-Franco et al. [65] who postulated that the increased production of oxidative stress as a result of the persistent hyperglycaemic state is capable of producing oxidative damage to the macromolecules (lipids, carbohydrates, proteins, and nucleic acids).

Previous studies referred the histological changes observed in the diabetic pancreas to the reactive oxygen species (ROS) generation. Bogolepov [11] considered the vacuolation as one of the structural indications of permeability disorders of the membranes that could be caused by ROS mediated formation of lipid peroxides as mentioned by Halliwell and Chirico [27]. In turn, the disturbed plasma membrane integrity, and subsequent oedema could disrupt the intercellular junctions causing wide intercellular spaces [13].

As a result of increasing lipid peroxidation, lipid-containing membranes as Golgi and rER membranes were dilated as stated by El-Kordy and Alshahrani [20]. Moreover, Schönthal [61] stated that rER dilatation represented a well-documented ultrastructural response to ER stress that led to accumulation of unfolded, misfolded, insoluble or damaged proteins that might damage cellular functions and pose a threat to the cell survival. In addition, some studies referred the mitochondrial degeneration to the increased glucose concentration that overwhelms the mitochondrial electron transport chain by increasing the oxidative phosphorylation and generation of ROS [39].

From all the above, the beneficial effect of anise extract can be attributed to its hypoglycaemic and antioxidant properties as nearly all the histological alterations in the diabetic control group was linked primarily to the oxidative stress accompanying hyperglycaemic state. Moreover, anise extract exerted a marked improvement in the exocrine portion of pancreas mostly due to its ability to secrete insulin and hence preservation of acinar cells with significant decrease in serum amylase level compared to the diabetic control group. this was in line with Williams et al. [73] who referred the exocrine affection to loss of insulinotropic effects on acinar cells and considered this factor as a primary cause for exocrine affection in case of DM and with Akpan et al. [3] who referred increased amylase level in the diabetics to its leakage from the broken acini.

In addition to the role of ROS in the pathogenesis of DM [59], recent studies suggested a pivotal role of autophagy in DM [10]. Moreover, the connection between autophagy and apoptosis or other forms of cell death is a burgeoning area of research [25]. In accordance with this, a significant upregulation of beclin 1 , an autophagy regulator marker, and caspase 3 , an apoptotic marker, was observed immunohistochemically in the pancreas of the diabetic rats in the present study indicating the role of autophagy and apoptosis in DM. This may be attributed to the oxidative stress associated with the hyperglycaemic state.

This was in line with previous studies that revealed upregulation of caspase $3[43,45]$ in DM and they referred the activation of apoptotic pathway to the state of oxidative stress. Indeed, upregulation of beclin 1 in the diabetic group was in line with previous studies who demonstrated an elevated level of beclin 1 within the pancreatic tissues of diabetic rat using enzyme-linked immuosorbent assay [50] and in the diabetic retinopathy [76]. This may be an adaptive process to protect organisms during periods of enhanced cellular distress as clarified by Kang et al. [35]. Okasha et al. [50] demonstrated that DM leads to imbalances in the antioxidant capacity within the cell resulting in oxidative/nitrosative stress and suggested an intimate relationship between autophagy and ROS production as major pathogenic mechanisms of DM.

In this research, the diabetic group treated with anise extract showed a significant downregulation of beclin 1 and caspase 3 compared to the diabetic control group. This was attributed to its antioxidant properties. Although the molecular connections between autophagy and apoptosis are complex and still poorly understood [25], the previous researchers $[18,62,71]$ clarified that excessive autophagy leads to apoptotic cell death and that ROS induce both autophagy and apoptosis simultaneously.

Hence the anise extract exerted its beneficial role via its hypoglycaemic and antioxidant effects. This was consistent with Kucukkurt et al. [41] who clarified that supplementation of anise affects positively the antioxidant defence. The antioxidant activity of anise extract was studied previously $[7,58]$. They attributed its antioxidant properties to its high content of phenolic compounds. Kesharwani et al. [36]; Wintola and Afolayan [74] clarified that phenolic compounds are 
hydrogen donors, so they can scavenge free radicles and reduce oxidative damage.

\section{CONCLUSIONS}

From the results of this work, it could be concluded that aqueous anise extract alleviated the pancreatic damage in STZ-induced diabetes rat model via modulation of insulin secretion, oxidative stress, autophagy and apoptosis. Further studies are needed to throw more light on the effect of anise extract on different diabetic complications and to investigate the effect of different doses of anise extract on DM.

\section{REFERENCES}

1. Abdul-Hamid M, Moustafa N. Protective effect of curcumin on histopathology and ultrastructure of pancreas in the alloxan treated rats for induction of diabetes. J Basic Applied Zool. 2013; 66(4): 169-179, doi: 10.1016/j. jobaz.2013.07.003.

2. Aebi H. Catalase in vitro. Methods Enzymol. 1984; 105: 121-126, doi: 10.1016/s0076-6879(84)05016-3, indexed in Pubmed: 6727660.

3. Akpan H, Ekaidem I, Usoh I, et al. Effect of Aqueous Extract of Azadirachta indica (Neem) Leaves on Some Indices of Pancreatic Function in Alloxan-induced Diabetic Wistar Rats. Pharmacologia. 2012; 3(9): 420-425, doi: 10.5567/ pharmacologia.2012.420.425.

4. Akpan OU, Bassey RB, Agba BS, et al. Elevation of serum pancreatic amylase and distortion of pancreatic cyto-architecture in type 1 diabetes mellitus rats treated with Ocimum gratissimum. Niger Med J. 2014; 55(1): 34-38, doi: 10.4103/0300-1652.128157, indexed in Pubmed: 24970967.

5. Al Mofleh IA, Alhaider AA, Mossa JS, et al. Aqueous suspension of anise "Pimpinella anisum" protects rats against chemically induced gastric ulcers. World J Gastroenterol. 2007; 13(7): 1112-1118, doi: 10.3748/wjg.v13.i7.1112, indexed in Pubmed: 17373749.

6. Alshathly MR. Efficacy of Ginger (Zingiber officinale) in Ameliorating Streptozotocin-Induced Diabetic Liver Injury in Rats: Histological and Biochemical Studies. J Microsc Ultrastruct. 2019; 7(2): 91-101.

7. Amer A, Aly U. Antioxidant and antibacterial properties of anise (Pimpinella anisum L.). Egypt Pharmaceut J. 2019; 18(1): 68, doi: 10.4103/epj.epj_44_18.

8. Andallu B, Rajeshwari CU. Aniseeds (Pimpinella anisum L.) in Health and Disease. Nuts and Seeds in Health and Disease Prevention. 2011: 175-181, doi: 10.1016/b9780-12-375688-6.10020-9.

9. Bekara A, Hamadouche NA, Kahloula K, et al. Effect of Pimpinella anisum $L$ (Aniseed) Aqueous Extract against Lead (Pb) Neurotoxicity: Neurobehavioral Study. Int J Neurosci Behav Scien. 2015; 3(3): 32-40.

10. Bhattacharya $D$, Mukhopadhyay $M$, Bhattacharyya $M$, et al. Is autophagy associated with diabetes mellitus and its complications? A review. EXCLI J. 2018; 17: 709-720, doi: 10.17179/excli2018-1353, indexed in Pubmed: 30190661
11. Bogolepov NN. Ultrastructure of the Brain in Hypoxia (translated from Russian by Michael Burov) Mir. Publishers, Moscow, 1983: 68-80.

12. Campbell-Thompson M, Rodriguez-Calvo $\mathrm{T}$, Battaglia M. Abnormalities of the exocrine pancreas in type 1 diabetes. Curr Diab Rep. 2015; 15(10): 79, doi: 10.1007/s11892015-0653-y, indexed in Pubmed: 26318606.

13. Carvalho NS, Silva MM, Silva RO, et al. Protective effects of simvastatin against alendronate-induced gastric mucosal injury in rats. Dig Dis Sci. 2016; 61(2): 400-409, doi: 10.1007/s10620-015-3890-7, indexed in Pubmed: 26403426.

14. Chatzigeorgiou A, Halapas A, Kalafatakis K, et al. Review the use of animal models in the study of diabetes mellitus. In Vivo. 2009; 23: 245-258.

15. Chowdhury S, Ghosh S, Rashid K, et al. Deciphering the role of ferulic acid against streptozotocin-induced cellular stress in the cardiac tissue of diabetic rats. Food Chem Toxicol. 2016; 97: 187-198, doi: 10.1016/j.fct.2016.09.011, indexed in Pubmed: 27621051.

16. Cooppan R. General approach to the treatment of diabetes mellitus. In: Joslin's Diabetes Mellitus, CR Kahn, GC Weir, GL King, AM Jacobson, AC Moses, RT Smith, Eds. Lippincott Williams and Wilkans, Philadelphia, Pa, USA 2005: 587-596.

17. Del Rio D, Rodriguez-Mateos A, Spencer JPE, et al. Dietary (poly)phenolics in human health: structures, bioavailability, and evidence of protective effects against chronic diseases. Antioxid Redox Signal. 2013; 18(14): 1818-1892, doi: 10.1089/ars.2012.4581, indexed in Pubmed: 22794138.

18. Duan W, Jin X, Li Q, et al. Silibinin induced autophagic and apoptotic cell death in HT1080 cells through a reactive oxygen species pathway. J Pharmacol Sci. 2010; 113(1): 48-56, doi: 10.1254/jphs.09315fp, indexed in Pubmed: 20431246.

19. El-Desouki NI, Tabl GA, Abdel-Aziz KK, et al. Improvement in beta-islets of Langerhans in alloxan-induced diabetic rats by erythropoietin and spirulina. J Basic Applied Zool. 2015; 71: 20-31, doi: 10.1016/j.jobaz.2015.04.003.

20. El-Kordy EA, Alshahrani AM. Effect of genistein, a natural soy isoflavone, on pancreatic $\beta$-cells of streptozotocin-induced diabetic rats: Histological and immunohistochemical study. J Microsc Ultrastruct. 2015; 3(3): 108-119, doi: 10.1016/j.jmau.2015.03.005, indexed in Pubmed: 30023190.

21. El-Ouady F, Lahrach N, Ajebli M, et al. Antihyperglycemic effect of the aqueous extract of in normal and streptozotocin-induced diabetic rats. Cardiovasc Hematol Disord Drug Targets. 2020; 20(1): 54-63, doi: 10.2174/1871525 717666190612121516, indexed in Pubmed: 31195951.

22. Fadda W, Mansour F, El-Safti F, et al. Ameliorative effect of spirulina against streptozotocin-induced diabetic changes in the pancreas of adult male albino rats. Egypt J Histol. 2015; 38(3): 427-437, doi: 10.1097/01.ehx. $0000470654.45253 .8 \mathrm{c}$.

23. Fu Z, Gilbert ER, Liu D. Regulation of insulin synthesis and secretion and pancreatic beta-cell dysfunction in diabetes. Curr Diabetes Rev. 2013; 9(1): 25-53, indexed in Pubmed: 22974359.

24. Gülçın I, Oktay M, Kıreçcı E, et al. Screening of antioxidant and antimicrobial activities of anise (Pimpinella anisum L.) 
seed extracts. Food Chem. 2003; 83(3): 371-382, doi: 10.1016/s0308-8146(03)00098-0.

25. Gump JM, Thorburn A. Autophagy and apoptosis: what is the connection? Trends Cell Biol. 2011; 21(7): 387-392, doi: 10.1016/j.tcb.2011.03.007, indexed in Pubmed: 21561772.

26. Gürpınar T, Ekerbiçer N, Uysal N, et al. The effects of the melatonin treatment on the oxidative stress and apoptosis in diabetic eye and brain. Scien World J. 2012; 2012: 498489, doi:_10.1100/2012/498489, indexed in Pubmed: 22654617.

27. Halliwell B, Chirico S. Lipid peroxidation: its mechanism, measurement, and significance. Am J Clin Nutr. 1993; 57(5 Suppl): 715S-724S; discussion 724S, doi: 10.1093/ ajcn/57.5.715S, indexed in Pubmed: 8475889.

28. Hassan WN, Saed AM. Protective effect of anise fruit (Pimpinella anisum) against osteoporosis in rat model. Am J Biomed Scien. 2013; 1: 49-56.

29. Hosseinzadeh H, Tafaghodi M, Abedzadeh S, et al. Effect of aqueous and ethanolic extracts of Pimpinella anisum L. seeds on milk production in rats. J Acupunct Meridian Stud. 2014; 7(4): 211-216, doi: 10.1016/j. jams.2013.10.004, indexed in Pubmed:_25151455.

30. Iyer SR, Ullagaddi RC, Bondada A. Antihemolytic and anti-inflammatory activities of aniseed (Pimpinella anisum L. J Adv Pharmac Res Biosc. 2013; 1(2): 52-59.

31. Jelodar G, Mohsen M, Shahram S. Effect of walnut leaf, coriander and pomegranate on blood glucose and histopathology of pancreas of alloxan induced diabetic rats. Afr J Tradit Complement Altern Med. 2007; 4(3): 299-305, doi: 10.4314/ajtcam.v4i3.31223, indexed in Pubmed: 20161893.

32. Jiang $L$, Zhang $X$, Zheng $X$, et al. Apoptosis, senescence, and autophagy in rat nucleus pulposus cells: Implications for diabetic intervertebral disc degeneration. J Orthop Res. 2013; 31(5): 692-702, doi: 10.1002/jor.22289, indexed in Pubmed: 23238821.

33. Jiang $Y L$, Ning $Y, M a X L$, et al. Alteration of the proteome profile of the pancreas in diabetic rats induced by streptozotocin. Int J Mol Med. 2011; 28(2): 153-160, doi: 10.3892/ ijmm.2011.696, indexed in Pubmed: 21567075.

34. Kadan S. Anticancer activity of anise (Pimpinella anisum L.) seed extract. Open Nutraceuticals J. 2013; 6(1): 1-5, doi: $10.2174 / 1876396001306010001$.

35. Kang R, Zeh HJ, Lotze MT, et al. The Beclin 1 network regulates autophagy and apoptosis. Cell Death Differ. 2011; 18(4): 571-580, doi: 10.1038/cdd.2010.191, indexed in Pubmed: 21311563.

36. Kesharwani RK, Singh DV, Misra K, et al. Plant polyphenols as electron donors for erythrocyte plasma membrane redox system: validation through in silico approach. Org Med Chem Lett. 2012; 2: 12, doi: 10.1186/2191-2858-2-12, indexed in Pubmed: 22475026.

37. Kluge R, Scherneck S, Schürmann A, et al. Pathophysiology and genetics of obesity and diabetes in the New Zealand obese mouse: a model of the human metabolic syndrome. Methods Mol Biol. 2012; 933: 59-73, doi: 10.1007/978-162703-068-7 5, indexed in Pubmed: 22893401.

38. Kono Y. Generation of superoxide radical during autoxidation of hydroxylamine and an assay for superoxide dismutase. Arch Biochem Biophys. 1978; 186(1): 189-195, doi: 10.1016/0003-9861(78)90479-4, indexed in Pubmed: 24422.

39. Kowluru RA, Mishra M. Oxidative stress, mitochondrial damage and diabetic retinopathy. Biochim Biophys Acta. 2015; 1852(11): 2474-2483, doi: 10.1016/j. bbadis.2015.08.001, indexed in Pubmed: 26248057.

40. Kreydiyyeh SI, Usta J, Knio K, et al. Aniseed oil increases glucose absorption and reduces urine output in the rat. Life Sci. 2003; 74(5): 663-673, doi: 10.1016/j. Ifs.2003.07.013, indexed in Pubmed: 14623036.

41. Kucukkurt I, Avci G, Eryavuz A, et al. Effects of Supplementation of Aniseed (Pimpinella anisum L.) at Various Amounts to Diets on Lipid Peroxidation, Antioxidant Activity and Some Biochemical Parameters in Laying Quails (Coturnix coturnix japonica). Kocatepe Vet J. 2009; 2(1): 1-5.

42. Kumar HR, Gowdappa HB, Hosmani T, et al. Exocrine dysfunction correlates with endocrinal impairment of pancreas in type 2 diabetes mellitus. Indian J Endocrinol Metab. 2018; 22(1): 121-125, doi: 10.4103/ijem.IJEM_139_17, indexed in Pubmed: 29535950.

43. Liu L, Du X, Zhang Z, et al. Trigonelline inhibits caspase 3 to protect $\beta$ cells apoptosis in streptozotocin-induced type 1 diabetic mice. Eur J Pharmacol. 2018; 836: 115-121, doi: 10.1016/j.ejphar.2018.08.025, indexed in Pubmed:_30130525.

44. Lucchesi AN, Freitas NT, Cassettari LL, et al. Diabetes mellitus triggers oxidative stress in the liver of alloxan-treated rats: a mechanism for diabetic chronic liver disease. Acta Cir Bras. 2013; 28(7): 502-508, doi: 10.1590/s010286502013000700005 , indexed in Pubmed: 23842931.

45. Matsunami T, Sato $Y$, Hasegawa $Y$, et al. Enhancement of reactive oxygen species and induction of apoptosis in streptozotocin-induced diabetic rats under hyperbaric oxygen exposure. Int J Clin Exp Pathol. 2011; 4(3): 255-266, indexed in Pubmed: 21487521.

46. Meier JJ, Bonadonna RC. Role of reduced $\beta$-cell mass versus impaired $\beta$-cell function in the pathogenesis of type 2 diabetes. Diabetes Care. 2013; 36 Suppl 2: S113-S119, doi: 10.2337/dcS13-2008, indexed in Pubmed: 23882035.

47. Nurdiana S, Goh YM, Ahmad H, et al. Changes in pancreatic histology, insulin secretion and oxidative status in diabetic rats following treatment with Ficus deltoidea and vitexin. BMC Complement Altern Med. 2017; 17(1): 290, doi: 10.1186/s12906-017-1762-8, indexed in Pubmed: 28576138.

48. Ogurtsova $K$, da Rocha Fernandes JD, Huang Y, et al. IDF Diabetes Atlas: Global estimates for the prevalence of diabetes for 2015 and 2040. Diabetes Res Clin Pract. 2017; 128: 40-50, doi: 10.1016/j.diabres.2017.03.024, indexed in Pubmed: 28437734.

49. Ohkawa H, Ohishi N, Yagi K. Assay for lipid peroxides in animal tissues by thiobarbituric acid reaction. Anal Biochem. 1979; 95(2): 351-358, doi: 10.1016/0003-2697(79)90738-3, indexed in Pubmed: 36810.

50. Okasha A, Gaballah H, Zakaria S, et al. Role of autophagy and oxidative stress in experimental diabetes in rats. Tanta Med J. 2017; 45(3): 122, doi: 10.4103/tmj.tmj_2_17.

51. Ortiz AR, Garcia JS, Castillo EP, et al. Alpha-glucosidase inhibitory activity of the methanolic extract from Tournefortia hartwegiana: an antihyperglycemic agent. J Ethnopharmacol. 2007; 109(1): 48-53. 
52. Pourgholami MH, Majzoob S, Javadi M, et al. The fruit essential oil of Pimpinella anisum exerts anticonvulsant effects in mice. J Ethnopharmacol. 1999; 66(2): 211-215, doi: 10.1016/s0378-8741(98)00161-5, indexed in Pubmed: 10433480 .

53. Rajeshwari U, Shobha I, Andallu B. Comparison of aniseeds and coriander seeds for antidiabetic, hypolipidemic and antioxidant activities. Spatula DD — Peer Reviewed Journal on Complementary Medicine and Drug Discovery. 2011; 1(1): 9, doi: 10.5455/spatula.20110106123144.

54. Ramesh J, Ronsard L, Gao A, et al. Autophagy intertwines with different diseases-recent strategies for therapeutic approaches. Diseases. 2019; 7(1), doi: 10.3390/diseases7010015, indexed in Pubmed: 30717078.

55. Ramudu SK, Korivi M, Kesireddy N, et al. Nephro-protective effects of a ginger extract on cytosolic and mitochondrial enzymes against streptozotocin (STZ)-induced diabetic complications in rats. Chin J Physiol. 2011; 54(2): 79-86, doi: 10.4077/cjp.2011.amm006, indexed in Pubmed: 21789888.

56. Rashid K, Sil PC. Curcumin enhances recovery of pancreatic islets from cellular stress induced inflammation and apoptosis in diabetic rats. Toxicol Appl Pharmacol. 2015; 282(3): 297-310, doi:10.1016/j.taap.2014.12.003, indexed in Pubmed: 25541178.

57. Rebey IB, Bourgou S, Wannes WA, et al. Comparative assessment of phytochemical profiles and antioxidant properties of Tunisian and Egyptian anise (Pimpinella anisum L.) seeds. Plant Biosystems - An International Journal Dealing with all Aspects of Plant Biology. 2017; 152(5): 971-978, doi: 10.1080/11263504.2017.1403394.

58. Rebey IB, Wannes WA, Kaab S, et al. Bioactive compounds and antioxidant activity of Pimpinella anisum L. accessions at different ripening stages. Scientia Horticulturae. 2019; 246: 453-461, doi:_10.1016/j.scienta.2018.11.016.

59. Réus GZ, Carlessi AS, Silva RH, et al. Relationship of oxidative stress as a link between diabetes mellitus and major depressive disorder. Oxid Med Cell Longev. 2019; 2019: 8637970 , doi: 10.1155/2019/8637970, indexed in Pubmed: 30944699.

60. Sangameswaran B, Ilango K. Evaluation Anti-hyperglycemic and antihyperlipidaemic activities of Andrographis lineata Nees on Streptozotocin induced diabetic Rats. Jordan J Biol Scien. 2010; 3(3): 83-86.

61. Schönthal AH. Endoplasmic reticulum stress: its role in disease and novel prospects for therapy. Scientifica (Cairo). 2012; 2012: 857516, doi: 10.6064/2012/857516, indexed in Pubmed: 24278747.

62. Scott RC, Juhász G, Neufeld TP. Direct induction of autophagy by Atg1 inhibits cell growth and induces apoptotic cell death. Curr Biol. 2007; 17(1): 1-11, doi: 10.1016/j. cub.2006.10.053, indexed in Pubmed: 17208179.

63. Sharma A, Gupta R. Anti-Hyperglycemic activity of aqueous extracts of some medicinal plants on wistar rats. J Diabetes Metab. 2017; 08(07), doi: 10.4172/21556156.1000752.

64. Shobha R, Andallu B. Antioxidant, anti-diabetic and hypolipidemic effects of aniseeds (pimpinella anisum L.): in vitro and in vivo studies. J Complement Med Alt Healthcare. 2018; 5(2), doi: 10.19080/jcmah.2018.05.555656.

65. Sifuentes-Franco S, Padilla-Tejeda DE, Carrillo-Ibarra S, et al. Oxidative stress, apoptosis, and mitochondrial function in diabetic nephropathy. Int J Endocrinol. 2018; 2018: 1875870 , doi: $10.1155 / 2018 / 1875870$, indexed in Pubmed: 29808088.

66. Sorour H, Selim M, EL-Moselhy LE, et al. Ameliorative effect of watermelon rind ingestion on the pancreas of diabetic female albino rat (histological, immunohistochemical and morphometric study). Egypt J Histol. 2019; 42(1): 10-22, doi: 10.21608/ejh.2018.4243.1018.

67. Srinivasan K, Ramarao P. Animal models in type 2 diabetes research: an overview. Indian J Med Res. 2007; 125(3): 451-472, indexed in Pubmed: 17496368.

68. Srinivasan K, Viswanad B, Asrat L, et al. Combination of high-fat diet-fed and low-dose streptozotocin-treated rat: a model for type 2 diabetes and pharmacological screening. Pharmacol Res. 2005; 52(4): 313-320, doi: 10.1016/j. phrs.2005.05.004, indexed in Pubmed: 15979893.

69. Szkudelski T. The mechanism of alloxan and streptozotocin action in B cells of the rat pancreas. Physiol Res. 2001; 50(6): 537-546.

70. Tourrel C, Bailbé D, Meile MJ, et al. Glucagon-like peptide-1 and exendin-4 stimulate beta-cell neogenesis in streptozotocin-treated newborn rats resulting in persistently improved glucose homeostasis at adult age. Diabetes. 2001; 50(7): 1562-1570, doi: 10.2337/diabetes.50.7.1562, indexed in Pubmed: 11423477.

71. Trejo-Solís C, Jimenez-Farfan D, Rodriguez-Enriquez S, et al. Copper compound induces autophagy and apoptosis of glioma cells by reactive oxygen species and JNK activation. BMC Cancer. 2012; 12: 156, doi: 10.1186/1471-2407-12156, indexed in Pubmed: 22540380.

72. Whiting DR, Guariguata L, Weil C, et al. IDF diabetes atlas: global estimates of the prevalence of diabetes for 2011 and 2030. Diabetes Res Clin Pract. 2011; 94(3): 311-321, doi: 10.1016/j.diabres.2011.10.029, indexed in Pubmed: 22079683.

73. Williams AJK, Thrower SL, Sequeiros IM, et al. Pancreatic volume is reduced in adult patients with recently diagnosed type 1 diabetes. J Clin Endocrinol Metab. 2012; 97(11): E2109-E2113, doi: 10.1210/jc.2012-1815, indexed in Pubmed: 22879632.

74. Wintola OA, Afolayan AJ. The antibacterial, phytochemicals and antioxidants evaluation of the root extracts of Hydnora africanaThunb. used as antidysenteric in Eastern Cape Province, South Africa. BMC Complement Altern Med. 2015; 15: 307, doi: 10.1186/s12906-015-0835-9, indexed in Pubmed: 26335685.

75. Wu KK, Huan Y. Streptozotocin-induced diabetic models in mice and rats. Curr Protoc Pharmacol. 2008; Chapter 5: Unit 5.47, doi: 10.1002/0471141755.ph0547s40, indexed in Pubmed: 22294227.

76. Zhang MP, Wu WH, Zhang Q, et al. The study on the beclin1 expression and change in diabetic rats. Sichuan Da Xue Xue Bao Yi Xue Ban. 2011; 42(4): 508-522. 